Acta Poloniae Historica

107,2013

PL ISSN 0001-6892

Jan Kieniewicz

\title{
THE EASTERN FRONTIERS AND THE CIVILISATIONAL DIMENSION OF EUROPE
}

In the times when Europe was organised by superpowers, in the century between the Congress of Vienna and the Treaty of Versailles, the continent's eastern part was split amongst three monarchs: the Russian and Austrian emperors and the King of Prussia. With time, the last of them became the emperor of Germany. In that world, the civilisational dimension of Europe and its political borders appeared to be the same, even despite the doubts that Europeans of the day voiced over Russia belonging to Europe, and regardless of how Russians or the English identified themselves in relation to Europe. These were not simple issues from the point of view of people who - being subjects of three monarchs - felt themselves to have a separate identity. Stripped of their own statehoods, they sought expression for their national identity in emphasising their European civilisational affiliation. This was an affiliation felt, or at least intuitively expressed, by Poles, Hungarians and Czechs, for example.

The Poles were a special case, as a nation divided amongst three monarchs. Defining their distinctiveness amongst Slavs, the Poles denied an affinity with Russia and wanted to be perceived as Europeans. Seeking the coordinates of his affiliation 160 years ago, Cyprian Norwid, a Polish poet who created his works as an émigré in Paris, called himself 'a stupid Slav'. ${ }^{1}$ As such, he saw himself as someone separate from and superior to the idea that West and East, and South and North could be understood as distinct forms of life. One could say that Norwid thus identified himself as a member of a nation while at the same time emphatically defining his civilisational membership. However, what kind of world was it that the Pole - as expressed

${ }^{1}$ Cyprian Norwid, Pieśn od ziemi naszej [Song from Our Land] (1850). 
by the poet - wanted to connect his separate existence to irrespective of the current political conditions?

The Pole who announced sovereignty of the spirit determined his centre. That centre, his 'capital and castle', was the land "where the last gallows shine". And where did he place the boundary of his being? Not just in relation to Whom but in the name of What? The poet replies: "Brotherhood to peoples I shall give, once I dry the tears". Consequently, he puts forward the fundamental problem of his own identity, self-knowledge by reference to the other: 'the other' within the same affiliation and the other - the stranger, identified from the perspective of remembering a shared space described as 'the Borderland'. This problem can be viewed as being universal.

Borderland is never a category used freely. It always defines people in a major way and decides about the nature of their relations with others and strangers. We cannot speak of 'the Borderland' without defining the borders, without identifying them. The question is: the borders of what, or perhaps, whose borders are they? We have to consider the political and ethnic dimensions of borders while also accounting for the much less palpable spaces of cultures and civilisations.

What, then, can European borders be in the third millennium, i.e. in our contemporary reality, but also in our future as a dimension that is essential to our existence?

Deciding to reflect on 'the Borderland', meaning Europe's Eastern frontiers, we need to specify a number of parameters, the most obvious being that of changeability over time. For this reason precisely, I would like to suggest that we look at the issue of European borders and borderlands over a very long time scale. When I assume thinking in terms of the third millennium, I do not mean the standard chronology according to which we have just begun the second decade. From the civilisational perspective proposed here, the third millennium began more than two centuries ago. ${ }^{3}$

2 Jan Kieniewicz, 'Ukraina: w stronę dialogu', in idem, Spotkania Wschodu (Gdańsk, 1999), 155. The first version of this text was published in Przeglad Powszechny, cxiii (1996), no. 10 (893).

${ }^{3}$ I originally offered this thought in 'Granice europejskie - trzecie tysiąclecie', Przeglad Powszechny, cxxviii (2011), no. 3(1075), 11-19, where it became the subject of a broader discussion. 
I would put a historical dividing line in the year 800 , when the reach of the future European civilisation was defined by the Carolingian empire.

The radical change of the geopolitical situation after Charlemagne destroyed the might of the Avars in 799 and their 'empire' disintegrated in 804, caused two different 'civilisations' to stand opposite each other along a long front line cutting across the entire continent: the aggressive empire of the Franks and the apparently politically passive Slavic peoples. ${ }^{4}$

The very same aggressiveness halted the progress of Muslim expansion, creating a different kind of civilisational borderland in the south-west. ${ }^{5}$ In the east, however, expansion did not stop the foreign civilisation but absorbed it; in the course of a few centuries opposition became a process not so much of synthesis but rather an original enculturation. The 'Younger Europe' was born. ${ }^{6}$ The same dividing line stems from the northward shift of the main focus as far as economic activity is concerned. ${ }^{7}$ This meant the opening of a new economic situation for the Eastern lands. Younger would not mean worse or backward. True to a very old tradition dating back to Ottonian times, such a term emphasises that these were different speeds of the same process of evolution. Jenó Szúcs proposed a perception that sees three Europes: Western, Eastern, and East-Central. ${ }^{8}$ Oskar Halecki saw Europe as a single but diverse space. ${ }^{9}$ Henryk Samsonowicz noted that in this day and age, a division into Northern and Southern Europe would be equally justified. ${ }^{10}$ Edgar Morin pointed out that Europe was characterised not so much by a division as by an internal unity of opposites, all of which forms a creative tourbillon dialogique. ${ }^{11}$

${ }^{4}$ Przemysław Urbańczyk, Trudne początki Polski (Wrocław, 2008), 52.

${ }^{5}$ Jan Kieniewicz, 'Andaluzja, Hiszpania i pogranicza cywilizacji: współczesna perspektywa historycznej konfrontacji', in Maciej Koźmiński (ed.), Cywilizacja europejska. Wyktady i eseje (Warsaw, 2004), 79-89.

${ }^{6}$ Jerzy Kłoczowski, Młodsza Europa. Europa Środkowo-Wschodnia w kręgu cywilizacji chrześcijańskiej średniowiecza (Warsaw, 1998).

${ }^{7}$ Michael McCormick, Origins of the European Economy: Communications and Commerce AD 300-900 (Cambridge, 2001).

${ }^{8}$ Jenő Szűcs, Les trois Europes, trans. Véronique Charaire et al., introd. Fernand Braudel (Paris, 1985).

${ }^{9}$ Oskar Halecki, The Limits and Divisions of European History (London and New York, 1950).

${ }^{10}$ Henryk Samsonowicz, Pótnoc - Południe (Wrocław, 1999).

${ }^{11}$ Edgar Morin, Penser l'Europe (Paris, 1987). 
In my reasoning, I will not seek divisions. The vision I favour is rather that of the formation of different varieties of Europe understood as a form of civilisation. This is why I suggest we look at the South and North regions as affecting the emergence of Europe as a civilisation. 'Europe in the east' developed as a consequence of changes occurring in the northern area of this space between the seas, though just like any other form of European civilisation, it had roots reaching into the southern area, into the Mediterranean tradition.

Is there a sensible dividing line to be drawn for the 'first millennium' in the 'northern area's' case? I find it advisable to separate that reality (Slavic or pre-Slavic, in any case - barbarian) from the Mediterranean world generating a succession of civilisational forms. The first millennium needs to be defined with regards to the external factors that shaped the northern world and then defined its successive forms of civilisation. For this reason, I would take Caesar's conquest of Gaul as the starting point for the 'first millennium'. ${ }^{12}$ This world later became the deciding factor due to the expansion triggered amongst barbarian peoples and directed towards the east, towards territories offering prospects for conversion.

For the eastern part of the northern region, pressure and pulling from the Eastern Empire and its civilisation would become equally important but not decisive. A decisive role, on the other hand, would be played by waves of expansion of nomadic peoples. The Steppe civilisations turned out to be another formative factor: in the course of a thousand years the Huns, Avars, Magyars and Mongols broke into the space inhabited by a settled population. This went on until Russia began its expansion towards the steppe. ${ }^{13}$

We need to define the end of the second millennium, too. It is determined by the formation of Europe as a political concept as well as in a civilisational sense. The second millennium was the time when Europe emerged, dealt with invasions, and began its own expansion in practically all directions. In the final stage, that first Europe would articulate its awareness and break away from the initial shape defined by Latin Christianity. The symbolic ending point for that period was the French Revolution which opened the modern contemporary era.

12 Karol Modzelewski, Barbarzyńska Europa (Warsaw, 2004).

${ }^{13}$ Michael Khodarkovsky, Russia's Steppe Frontier: The Making of a Colonial Empire, 1500-1800 (Bloomington, 2002). 
On the other hand, though, arguments can be found for treating the third millennium as the post-Westphalian era, the time of the birth as well as the decline of capitalism.

The problem presented here concerns the area described as the East of the continent, sometimes referred to as the 'Intermarium', a territory bringing together four directions of the world. It was here that we located our 'castle', our centre enabling us to define our borders. This is the distinctive feature of the Poland of old and this is how the 'Poles of old' defined themselves - by the ability to determine their borders and by the freedom to decide their affiliations. ${ }^{14}$ That does not mean, however, that this is a constant and unchanging phenomenon. What decides about borders in a horizon of millennia are civilisations, i.e. the relations between people invoking different value systems, developing different ways of living. ${ }^{15}$

Let us see what centres and what borders in the second millennium affected the configuration of inter-civilisational relations in the extensive territories of the continent's eastern part. I present them in succession fully aware that the adopted criteria are arbitrary.

1. The area between the rivers Elbe and Dnepr did not stand out, with the exception of two circumstances that turned out to be permanent in the second millennium:

- the space between the Baltic and Black Seas ('Intermarium', in Polish: Międzymorze) was open in both the east-west and northsouth directions;

- establishing rule over this space required relating to the forms of civilisation defined by Latin and Greek Christianity (Roman Catholic and Orthodox).

2. The time before the year 1000 saw the development of state organisms mapping out borders that reflected the reach of sovereign rule.

3 . These organisms existed in relation to independent external systems such as Byzantium, the Empire, Khazaria, or the Norman world. The influence of these systems was obvious but did not create borders; the centres were too far away, until expansion (German,

${ }^{14}$ I outline this issue in Jan Kieniewicz, 'Jaka ojczyzna Juliusza Słowackiego?', in Profesor Jolancie Żurawskiej. Studia ofiarowane przez przyjaciót $i$ kolegów (Cracow etc., 2008), 114.

${ }^{15}$ Yan Kenevich [Jan Kieniewicz], 'Vybor tsennosteĭ i tsivilizatsionnaya prinadlezhnost': vozmozhnost' ili neobkhodimost'?', in idem (ed.), Tsivilizatsionnyı vybor i pogranich'e (Debaty IBI AL, 4, Warsaw, 2011), 328-37. 
Norman) resulted in direct contact. In other words, the emerging organisms' own borders met the borders that defined the reach of the expansion of bigger and more organised units. With respect to equal organisms, the emerging state centres were driven by short-term motivations and not an actual plan.

4. Two clear axes of concentration became visible around the year 1000 (similar to the western axis linking Lombardy with the Netherlands): ${ }^{16}$

- in the east, it was the Dnepr, and it emerged sooner due to Scandinavian-Byzantine connections;

- in the west, it was the Gdańsk-Lvov-Kaffa route; this prospect for integration revealed itself later.

This is why the origins of Ruthenian and Polish statehood were not identical.

5. External pressure in the form of a threat turned out to be stimulating, borders reflecting an ability to offer resistance or the possibility of achieving supremacy began to emerge:

- this was the western border on the Oder for the Polans (whoever they might have been);

- this was the western border on the River Bug for the Ruthenians (whatever we might think of them).

6. The Empire's territorial expansion meant a continuation of activity that was unrelated to the formation of eastern political centres and a lack of interest in controlling their axis of concentration. The boundaries of the Empire were open. The building of the eastern marches and the elimination of Western-Slavic tribal ties signalled new cultural trends and caused a response in the form of independent Christianisation. The first western border in the east shifted eastwards, but was chiefly an expression of acculturation. Between the tenth and thirteenth centuries, the Polish state centre progressed from a tribal union to a kingdom of Poles, which - after going through consecutive splits and unifications - was able to define itself territorially thanks to the Baltic-Black Sea axis.

7. Mongol expansion in the thirteenth century not only changed the configuration of power in the entire area east of the Dnepr, but

${ }^{16}$ Cf. idem, Wprowadzenie do historii cywilizacji Wschodu i Zachodu (Warsaw, 2003), 55. I previously presented this concept in Michał Tymowski, Jan Kieniewicz, and Jerzy Holzer, Historia Polski (Paris, 1986), 116. 
clearly weakened the integrative strength of the eastern (Ruthenian) axis. This might also have been the effect of new trends in the north (the Flemish impulse, the westward shift of the Hanseatic League).

8. The thirteenth century was a turning point. In the drive to control the Baltic-Black Sea axis, thanks to co-operation with Lithuania, the Poles gained an advantage over the Hungarians.

9. Polish expansion turned to the south-east, to the Black Sea, whereas the interests of the Ruthenian boyars suggested a stronger need to rebuild the Dnepr axis, i.e. towards Polotsk, Smolensk and Novgorod. The Dnepr axis was considered the key to Ruthenia; Lithuania and then Poland made a different and competitive form out of it.

10. The Dnepr axis began a revival in the fourteenth century, opening up prospects for the development of Lithuanian statehood and a separate form of civilisation. The weaker impact of elemental disasters, first and foremost the Black Death epidemic, was important for this process (and for Poland as well). The borders of the Grand Duchy of Lithuania in the east were not so much the effect of expansion as a consequence of the collapse of Ruthenian forms of statehood, caused by the Mongol invasion. This state of affairs continued until the emancipation of Moscow.

11. It was not until the fifteenth century that prospects for a civilisational border began to emerge, expressed in the concept of Asian and European Sarmatia. ${ }^{17}$ This was a consequence of the transformation of the Crown of the Kingdom of Poland (Corona Regni Poloniae) into the Republic or Polish-Lithuanian Commonwealth (Respublica Polonorum) as an original form of statehood (monarchia mixta).

12. The political border of the Polish-Lithuanian Commonwealth in the east in the fifteenth-sixteenth centuries was open, not only due to the special nature of this state. It had its own vertebral axis in its back regions, the Dnepr axis was not so much a desirable axis as one to be defended due to its importance to the opponent that was emerging in the form of the Grand Duchy of Moscow. The PolishLithuanian Commonwealth had to reconstruct its axis of concentration by including access to the Baltic (Novgorod and Narva as two stages). This defined the Muscovy problem for the entire period until the Russian empire came into being. ${ }^{18}$

${ }^{17}$ Jan Kieniewicz, 'Powrót na Wschód', in idem, Spotkania Wschodu, $221 \mathrm{ff}$.

18 Aleksandr B. Shirokrad, Pol'sha. Neprimirimoe sosedstvo (Moscow, 2011). 
13. Muscovy's political border in the west closed more and more as the recovery of the Dnepr axis turned out to be insufficient from the point of view of the capacity to create an integrating force. Muscovy began turning towards the east, it had to cope with the legacy of the Horde. ${ }^{19}$ Gaining control over the Dnepr axis continued until the eighteenth century because the configuration of power in the Mediterranean changed in the meantime. It became necessary to gain control over the axis thanks to which the Polish-Lithuanian Commonwealth functioned as well. That meant a challenge: who would shape Europe in the east?

14. The political border separating the Polish-Lithuanian Commonwealth from the Grand Duchy of Moscow became a civilisational one, the region linked to the Dnepr axis assumed the features of 'a Borderland' - this was the borderland of European civilisation characterised by the co-existence of people representing different civilisational affiliations. The borderland was open by its very nature, but it also turned into an area involved in a dispute which had a major impact on the transformation of Muscovy into Russia. From the east, the political border started to be perceived as a civilisational border, one that separated and enclosed while remaining provocative as well. ${ }^{20}$

That borderland was a European space. This means that the western borders were political, cultural and linguistic, but they did not separate worlds. Differences in economic systems and differences in the standard of living did not mean separateness or alienation. Religious differences did not create clear borders.

The end of the second millennium was in fact the birth of a new form of Europe; it was built by the Enlightenment, Science, Industry and Revolution. Bonaparte's European empire, yet another attempt to integrate the continent, gave a huge impulse to national processes. The new era began with European expansion leading to the formation of the West.

15. The westward shift of Russia's border from the late seventeenth to the late eighteenth century fulfilled the empire's fundamental political principles but failed to bring the expected advantage, because the

${ }^{19}$ Cf. the concepts of Lev N. Gumilëv, e.g. in idem, Ot Rusi k Rossii. Ocherki etnicheskoù istorii (Moscow, 1992).

${ }^{20}$ Aleksandr L. Yanov, Rossiya i Evropa, 1462-1921, pt. i: Evroperskoe stoletie Rossii, 1480-1560 (Moscow, 2008). 
Baltic-Black Sea axis was just beginning to lose its integrative power. The western border that was meant to include Russia in Europe began taking on an excluding role.

16. The partitioning of Poland, and then 1815, enabled Russia to move its western border across the River Vistula. Russia started to become part of the European concert, it was a key player on the chessboard of Europe, but it did not start to become European. The western border forced the empire's reorganisation in the western provinces and the formation of the Kingdom of Poland. The result was the ultimate closing of the border, cutting off the inhabitants of Polish, Lithuanian, Belarusian and Ukrainian lands from mutual ties and from correspondence with Europe. At the same time, this border met with the borders of European countries that followed a policy of expansion in the east - Prussia remained in the east with its own vision of a European mission and its concept of a natural border that would be Europe's frontier. ${ }^{21}$

17. The process of eliminating Europeanism from Eastern European lands led to a necessity for the West to develop as a form of civilisation that was cut off from the former territories of the PolishLithuanian Commonwealth. Borders divided not just lands, but people above all. The Prussian and Austrian partitions became European peripheries; they were sometimes treated like colonies but remained linked to Europe. The Russian partition was cut off from Europe, though some of its inhabitants could feel themselves to be Europeans. When modernisation began, models were taken from the West but domination from Russia remained.

18. The rebuilding of Poland after 1918 meant introducing a border that safeguarded no axis while dividing people, creating a sense of an undeserved wrong. Two borders would be the source of conflict in 1939. This conflict revealed the superpowers' obvious drive to secure their rule over some form of eastern Europe, which required shifting their own border either to the east or to the west. Obviously, any safe border in the east had to move beyond the Dnepr, while in the west, the position of a hegemonic leader could only be provided by a border on the Elbe. The post-war arrangements (after 1945) failed to resolve the problem, because the border in the west had to become

${ }^{21}$ Cf. Izabela Surynt, Postęp, kultura $i$ kolonializm. Polska a niemiecki projekt europejskiego Wschodu w dyskursach publicznych XIX wieku (Wrocław, 2006). 
a cordon and a wall instead of bringing the Soviet Union its expected rule over the continent.

19. The Soviet Union's disintegration led to the constitution of new countries and borders, but it did not automatically cause a change in their character. To all appearances, Russia's border returned to its location from the time of the Peace of Polanovo (1634), but those earlier axes of integration were gone. The European Union and the Schengen Agreement now define the nature of these borders. This means restoring the open character of the borders as they move eastwards. Halting this process at the River Bug does not resolve the thousand-year dilemma - as we might call it - of developing the 'Intermarium' as the eastern form of Europe and not as an area consolidating anyone's imperial aspirations. Rebuilding 'the Borderland' remains a suggestion, not a concept. ${ }^{22}$

20. In my view, the fundamental problem is how to describe the relationship between political borders and what we might call the reaches of civilisation. That means looking at the contemporary shifting of borders from the perspective of the millennium which, for our part of the world, began not with the French Revolution but with the Congress of Vienna. We need to identify the fundamental trends of this longest of continuations.

Amongst these, I see the question of the ability to identify a state of affiliation, in the sense of making civilisational choices. We face the still open problem of defining our centre within our independently determined borders (though aware that they have been imposed). Today, it is no longer symbolised by the 'final gallows'. Today, the centre of Polish work and Polish memory is defined by a conscious civilisational choice. This choice indicates that in our world, these borders are European, which enables us to find the ability to shape 'our Borderland' as a place for meetings between others and strangers. ${ }^{23}$

To quote my own opinion: Europe's eastern border can be perceived in turn as:

${ }^{22}$ Cf. Jan Kieniewicz, 'How to rebuild European Borderlands', in Hartmut Elsenhans (ed.), A Balanced European Architecture: Enlargement of the European Union to Central Europe and the Mediterranean/Une architecture européenne équilibrée: l'ouverture de l'Union européenne vers l'Europe centrale et la Méditerranée (Paris, 1999), 100-10.

${ }^{23}$ Yan Kenevich [Jan Kieniewicz], 'Obstoyatel'stva dialoga na pogranich'e: nekotorye razmyshleniya', in idem (ed.) Tsivilizatsionnyı vybor, 91-108. 
- a notion expressing the idea of the division of worlds, the differentiation between Sarmatia Asiana and Sarmatia Europeana between the fifteenth and seventeenth century;

- the determination of the range of Russian expansion between the seventeenth and nineteenth centuries;

- a conviction about the existence of a European core, which took the form of the West in the nineteenth and twentieth centuries;

- a line separating the Free World from the sphere of Soviet domination in the second half of the twentieth century;

- a concept of the range of the European Union between the Baltic and the Mediterranean Seas. ${ }^{24}$

The civilisational dimension of Europe was shaped in the third millennium. During this time, independent European projects in the East succumbed to erosion and disintegrated, leaving the open problem of determining the civilisational affiliation of the inhabitants. Borders defined their inability to make independent decisions, showing the limitations they faced in the implementation of modernisation processes. ${ }^{25}$ Overcoming these divisions is still the precondition for restoring Europe to its form of an open civilisation and one capable of expansion.

${ }^{24}$ Idem, 'The Eastern Frontier and the Borderland of Europe', in José Faraldo, Paulina Gulińska-Jurgiel, and Christian Domnitz (eds.), Europa im Ostblock. Vorstellungen und Diskurse (1945-1991)/Europe in the Eastern Bloc: Imaginations and Discourses (1945-1991) (Zeithistorische Studien, 44, Cologne etc., 2008), 87.

${ }^{25}$ Jan Kieniewicz, 'Political Violence, Civilizational Oppression, and Colonialism', in idem (ed.), Silent Intelligentsia: A Study of Civilizational Oppression (Warsaw, 2009), 20-58. 